\title{
Colorimetric Immunocapture Reverse Transcription Loop-Mediated Isothermal Amplification Assay for Rapid Detection of the Potato virus $Y$
}

\author{
Mohammad Amin Almasi ${ }^{1}$ and Seyedmohammad Hosseyni Dehabadi* \\ ${ }^{1}$ Department of Biotechnology, Research Institute of Physiology and Biotechnology, University of Zanjan, Zanjan, Iran \\ ${ }^{2}$ Young Researchers and Elite Club, Meybod Branch, Islamic Azad University, Meybod, Iran
}

\begin{abstract}
Loop-Mediated Isothermal Amplification (LAMP) assay is a novel technique for amplifying DNA under constant temperature, with high specificity, sensitivity, rapidity and efficiency. To diminish the time required for some diagnostic assays including Reverse Transcription PCR (RT-PCR), Reverse Transcription Loop-Mediated Isothermal Amplification (RT-LAMP) and also DAS-ELISA into a minimum level, an innovative colorimetric IC-RT-LAMP and IC-RT-PCR protocol on the basis of Potato Virus Y (PVY) genome were used and optimized. Firstly, DAS-ELISA assay was performed to detect of the virus in a collection containing 95 suspicious samples. Lastly, five samples were detected as the positive samples. Then, the positive samples were verified by molecular methods. In this regard, all four RT-LAMP primers (i.e. F3, B3, FIP and BIP) together with RT-PCR primers (F and B) were selected on the basis of coat protein gene (CP) of PVY genome. Even though DAS-ELISA, RT-PCR and RT-LAMP assays could successfully detect positive infected plant samples, considering the time, safety, sensitivity, cost and simplicity, the last one was overall superior. Furthermore, the results demonstrated that the RT-LAMP assay was 100 times sensitive and 3 time faster compared to RT-PCR. LAMP assay was accomplished in the water bath either frees from any thermal cycler machine or sophisticated laboratories facility. Meanwhile, among six different visual dyes to accurately detect IC-RT-LAMP products, Hydroxynaphthol blue, GeneFinder ${ }^{T M}$ and SYBR Green I could produce long stable colour change and brightness in a close tube-based approach to prevent cross-contamination risk, concluded eventually as the best ones. We accordingly propose this colorimetric assay as a highly reliable alternative viral recognition system regarding PVY recognition and probably other viral-based diseases.
\end{abstract}

Keywords: Colorimetric assay; DAS-ELISA assay; IC-RT-LAMP assay; IC-RT-PCR assay; Potato virus $Y$

\section{Introduction}

Potato (Solanum tuberosum L.), as the world's most important nongrain food crop [1]. Potato plants, like other crops, are exposed frequently to plenty of infectious viruses, economically the most important of which are Potato leafroll virus (PLRV, genus Polerovirus), Potato virus $Y$ (PVY, genus Potyvirus), Potato virus X (PVX, genus Potexvirus) and Potato virus S (PVS, genus Carlavirus) [2]. PVY, one species of the genus Potyvirus is a phloem-limited virus that infects potato leading to a significant reduction in potato annual yield as well as tuber quality worldwide [3,4]. As a result, fast, cost effective, reliable and sensitive indexing techniques are requisite tools to determine the virus. Some alternative approaches were gradually developed including DAS-ELISA [5,6], bioassay [7], and Polymerase Chain Reaction (PCR) [8], all of which were unfortunately time-consuming and require expensive or carcinogenic materials to visualize DNA amplification [6,9]. Meanwhile, extraction of RNA is another exhausting task, accomplished commonly under various protocols, all of which are typically accompanied by some drawbacks [10-12]. Among various isothermal amplification systems developed over the recent years, the most frequently applied approach seems to be loop-mediated isothermal amplification (LAMP), implemented first by Notomi et al. [13]. Due to its enormous rate of amplification paired with a very high specificity, sensitivity, rapidity and low artifact susceptibility], the method together with its modifications have been strongly recommended for detection of a great number of strains of bacteria as well as viruses worldwide [14-17]. Although a large number of studies have been accomplished using LAMP or RTLAMP including Potato virus Y [4], Potato Leafroll virus [18], Japanese yam mosaic potyvirus [19], Tomato Yellow Leaf Curl virus [20], Rabies virus [21], Macrobrachium rosenbergii nodavirus [22] and Cymbidium mosaic virus [23], all of which basically require more precise extraction protocol(s) about generating higher concentrations of DNA or RNA followed by the least amounts of probable contaminations which act as inhibitors in an amplification process. Notably, despite a few number of studies about immunocapture reverse transcription loopmediated isothermal amplification (IC-RT-LAMP) [17,24] because the technique has not been yet introduced for detection of PVY, an attempt was accordingly made to optimize a new protocol of it to save time and remove RNA extraction. As the second purpose, since the existence of one-step IC-RT-LAMP positive amplicons has been proved to be confirmed by adding a number of fluorescent dsDNA intercalating dye including ethidum bromide [25], SYBR Green [26] and propidium iodide [27] after the reaction is completed or metal indicators such as calcein [28], Gene-Finder ${ }^{\mathrm{TM}}$ [29,30], hydroxyl naphthol blue [31-33] and magnesium pyrophosphate $[17,18]$ prior to the reaction, allowing observation with the naked eye, here, six different visualization systems were consequently employed to assess the colour stability as well as safety feature of each one in a viral detection procedure of PVY.

*Corresponding author: Seyedmohammad Hosseyni Dehabadi, Young Researchers and Elite Club, Meybod Branch, Islamic Azad University, Meybod, Iran, E-mail: hoseynibio@gmail.com

Received June 24, 2013; Accepted July 11, 2013; Published July 15, 2013

Citation: Almasi MA, Dehabadi SH (2013) Colorimetric Immunocapture Reverse Transcription Loop-Mediated Isothermal Amplification Assay for Rapid Detection of the Potato virus Y. J Plant Pathol Microb 4: 188 doi:10.4172/2157-7471.1000188

Copyright: ( $) 2013$ Almasi MA, et al. This is an open-access article distributed under the terms of the Creative Commons Attribution License, which permits unrestricted use, distribution, and reproduction in any medium, provided the original author and source are credited. 
Citation: Almasi MA, Dehabadi SH (2013) Colorimetric Immunocapture Reverse Transcription Loop-Mediated Isothermal Amplification Assay for Rapid Detection of the Potato virus Y. J Plant Pathol Microb 4: 188 doi:10.4172/2157-7471.1000188

\section{Materials and Methods}

\section{Plant samples}

A total of 95 fresh potato leaf samples infected dubiously with PVY on the basis of plantsymptoms containing yellowing and erect leaves as well as plant stunting were collected from ten separate potato fields in Provinces Zanjan, Hamadan, Kordestan and East Azarbaijan of Iran.

\section{Double antibody sandwich enzyme linked immune sorbent assay (DAS-ELISA)}

DAS-ELISA was carried out as described by Clark and Adams [5] with some minor modifications, using a commercially available PVY IgG and the alkaline phosphatase-conjugated PVY IgG. Polystyrene microtiter plates were coated for $3 \mathrm{~h}$ at $34^{\circ} \mathrm{C}$, with $200 \mu \mathrm{l}$ per well of IgG coating, in $50 \mathrm{mM}$ carbonate buffer, $\mathrm{pH}$ 9.6. The plates were then incubated for $1 \mathrm{~h}$ at $34^{\circ} \mathrm{C}$ with PBS (10 mM phosphate buffer, $\mathrm{pH} 7.2$, $0.8 \% \mathrm{NaCl}$ and $0.02 \% \mathrm{KCl}$ ). After that, the plates were washed three times using washing buffer $(0.8 \% \mathrm{NaCl}, \mathrm{pH} 7.2$ and $0.05 \%$ Tween 20$)$. The infection-free (control) and PVY-infected potato leaf samples were ground in ten volumes (w/v) of PBS buffer $\mathrm{pH} 7.2$, containing $0.2 \%$ polyvinyl pyrrolidone and $2 \%$ of egg albumin (Sigma A5253).The infected preparations were serially diluted (fivefold dilution) at the same buffer. Aliquots of $195 \mu \mathrm{l}$ of prepared samples were added to each well, and the plates were incubated overnight at $4^{\circ} \mathrm{C}$. Plates were then washed three times with washing buffer, incubated for $4 \mathrm{~h}$ at $37^{\circ} \mathrm{C}$, with $190 \mu \mathrm{l}$ per well of alkaline phosphatase-conjugated PVY IgG diluted in sample buffer, washed again, and incubated lastly for $90 \mathrm{~min}$, with p-nitrophenylphosphate $(1 \mathrm{mg} / \mathrm{ml})$, in $10 \%$ diethanolamine, $\mathrm{pH} 9.8$. Data were expressed and recorded using Multiskan at $\mathrm{A}_{405} \mathrm{~nm}$.

\section{RT-PCR assay}

RNA was purified from PVY-infected potato leaves according to former protocol [34]. Extracted RNA (5 $\mu$ l) was incubated at $75^{\circ} \mathrm{C}$ for $3 \mathrm{~min}$ and chilled on ice for $3 \mathrm{~min}$. The RT-PCR was developed using a PVY-specific primer designed on the basis of virus coat protein (CP) gene (Table 1) [4]. First, 20 pmol backward (B) primer, $50 \mathrm{mM}$ Tris-HCL, pH 8.3, $10 \mathrm{mM}$ dithiothreithol (DTT), $2.5 \mathrm{mM} \mathrm{MgCl}, 10$ $\mathrm{mM}$ of each dNTP (dATP, dTTP, dCTP and dGTP), $5 \mathrm{U}$ of RNasin Ribonuclease Inhibitor (Fermentas Co, Cat. No EO0381), and $1.25 \mathrm{U}$ of Avian myeloblastosis virus (AMV) reverse transcriptase (Fermentas Co, cat. no. EP0641) were added to RNA. Afterwards, mixtures were incubated at $60^{\circ} \mathrm{C}$ for $60 \mathrm{~min}$. lastly; the obtained cDNA was incubated $(2 \mu \mathrm{l})$ was incubated at $95^{\circ} \mathrm{C}$ for $5 \mathrm{~min}$ and chilled on ice and it was served as a template in PCR reaction. PCR reaction was carried out on a Thermal Cycler (iCycler, BIO RAD, CA, USA) in a $25 \mu$ l volume containing $1 \times$ PCR buffer $(10 \mathrm{mM}$ Tris-HCL, $\mathrm{pH} 8.3,50 \mathrm{mM} \mathrm{KCl})$, $1.5 \mathrm{mM} \mathrm{MgCl}_{2}, 0.2 \mathrm{mM}$ of each dNTP, 20 pmol of each forward and backward primers, $0.625 \mathrm{U}$ of Taq DNA polymerase (Cinagen Co, Cat. No TA7505C) and $2 \mu \mathrm{l}$ cDNA. Subsequently, mastermix were amplified at $94^{\circ} \mathrm{C}$ for $3 \mathrm{~min}$; for 35 cycles followed by for $1 \mathrm{~min}$ at $94^{\circ} \mathrm{C}, 1 \mathrm{~min}$ at $54^{\circ} \mathrm{C}, 1 \mathrm{~min}$ at $72^{\circ} \mathrm{C}$. A final extension was accomplished for $10 \mathrm{~min}$ at $72^{\circ} \mathrm{C}$. The products were lastly analyzed by gel electrophoresis in which $5 \mu \mathrm{l}$ of the products (480 bp) was loaded on a 1.5\% agarose gel and visualized by staining with ethidium bromide.

\section{RT-LAMP assay}

In order to perform RT-LAMP, on the basis of CP gene of the PVY genome, four specific primers including outer primers (F3 and B3) and inner primers (FIP and BIP) were used (Table 1) [4]. RT-LAMP reaction was performed in a total volume of $50 \mu \mathrm{l}: 5 \mu \mathrm{l}$ of RNA, $10 \mathrm{mM}$ DTT, 5 $\mathrm{U}$ of RNase Ribonuclease Inhibitor (Fermentas Co., cat. no. EO0381), $20 \mathrm{mM}$ Tris- $\mathrm{HCl}, \mathrm{pH} 8.8,10 \mathrm{mM} \mathrm{KCl}, 10 \mathrm{mM}\left(\mathrm{NH}_{4}\right)_{2} \mathrm{SO}_{4}, 0.1 \%$ Triton X-100, 2 mM Betaine (Sigma-Aldrich, Oakville, ON, Canada), $1 \mathrm{mM}$ $\mathrm{MgSO}_{4}, 10 \mathrm{mM}$ each dNTP, $0.2 \mu \mathrm{M}$ each of F3 and B3, $0.8 \mu \mathrm{M}$ each of primer FIP and BIP, $1.25 \mathrm{U}$ of AMV reverse transcriptase (Fermentas Co., cat. no.EP0641) and 8 U of Bst DNA polymerase (New England Biolabs Inc.). Tubes were then incubated at $60^{\circ} \mathrm{C}$ for $90 \mathrm{~min}$ in water bath. It is noticeable that the first $45 \mathrm{~min}$ is allocated only to synthesize cDNA, while in the second round, LAMP amplicons are amplified. An agarose gel electrophoresis system (optional; 1.5\%) under UV illumination could be also employed to visualize positive reactions: $5 \mu \mathrm{l}$ of each product is loaded on a $1.5 \%$ agarose gel.

\section{IC-RT-PCR assay}

The IC-RT-PCR was developed using a PVY-specific primer designed on the basis of virus coat protein (CP) gene (Table 1) [4] The protocol, to generate IC-RT-PCR products, was divided into two successive sections as below:

Section 1: The same as DAS-ELISA method, here, PCR tubes were first coated with PVY specific IgG diluted in coating buffer and incubated for $4 \mathrm{~h}$ in $37^{\circ} \mathrm{C}$. Tubes, in the following, were washed with washing buffer (see "DAS-ELISA Assay" section). The extractions of positive potato samples (i.e. previously detected by DAS-ELISA assay as positive control) and a free virus plant sample (as negative control) were added to IgG-coated tubes and kept overnight at $4^{\circ} \mathrm{C}$. Tubes, the next day, these were washed using washing buffer, dried and employed as RNA template in IC-RT-PCR reactions.

Section 2: In this part, the reaction was carried out in a Bio-Rad thermocycler. The amplification was performed in a $40 \mu \mathrm{l}$ volume containing 20 pmol of each backward and forward primers ( $\mathrm{F}$ and $\mathrm{B}$ ), $10 \mathrm{mM}$ dithiothreithol (DTT), $2.5 \mathrm{mM} \mathrm{MgCl}_{2}, 10 \mathrm{mM}$ of each dNTP, 5 $\mathrm{U}$ of RNasin Ribonuclease Inhibitor (Fermentas Co, cat. no. EO0381), $1.25 \mathrm{U}$ of Avian myeloblastosis virus (AMV) reverse transcriptase (Fermentas Co, cat. no. EP0641), 1× PCR buffer (10 mM Tris-HCL, $\mathrm{pH} 8.3,50 \mathrm{mM} \mathrm{KCl}$ ) and $0.625 \mathrm{U}$ of Taq DNA polymerase (Cinagen Co, cat. no.TA7505C). First, strand of cDNA was amplified at $60^{\circ} \mathrm{C}$ for 60 min from RNA extracted by immunocapture method using the backward primer. One set of primer (Table 1), that is backward and forward primers, was used for the PCR amplification of the CDNA. Amplification was performed with the following PCR profile: $94^{\circ} \mathrm{C}$ for $3 \mathrm{~min} ; 35$ cycles of $1 \mathrm{~min}$ at $94^{\circ} \mathrm{C}, 1 \mathrm{~min}$ at $54^{\circ} \mathrm{C}, 1 \mathrm{~min}$ at $72^{\circ} \mathrm{C}$ and 10

\begin{tabular}{|c|c|c|c|c|}
\hline Primer & Type & Position on gene & Length & Sequence (5'-3') \\
\hline $\mathrm{F}$ & Forward & $8721-8740$ & 20 mer & ACGTCCAAAATGAGAATGCC \\
\hline B & Backward & $9181-9200$ & 20 mer & TGGTGTTCGTGATGTGACCT \\
\hline F3 & Forward outer & $8870-8890$ & 21 mer & ATACGACATAGGAGAAACTGA \\
\hline B3 & Backward outer & $9059-9078$ & 20 mer & ACGCTTCTGCAACATCTGAG \\
\hline FIP & Forward inner & $8931-8951$ and $8900-8920$ & 42 mer & GTTTGGCGAGGTTCCATTTTC-TGTGATGAATGGGCTTATGGT \\
\hline BIP & Backward inner & 9004-9024 and 9036-9056 & 42 mer & TGAAACCAATCGTTGAGAATG-ATGTGCCATGATTTGCCTAAG \\
\hline
\end{tabular}

Table 1: Oligonucleotide primers used for one-step colorimetric IC-RT-LAMP and one-step IC-RT-PCR for detection CP gene of PVY. 
Citation: Almasi MA, Dehabadi SH (2013) Colorimetric Immunocapture Reverse Transcription Loop-Mediated Isothermal Amplification Assay for Rapid Detection of the Potato virus Y. J Plant Pathol Microb 4: 188 doi:10.4172/2157-7471.1000188

Page 3 of 6

min at $72^{\circ} \mathrm{C}$ for final extension. The products were lastly analyzed by gel electrophoresis and visualized by staining with ethidium bromide.

\section{IC-RT-LAMP assay}

In order to perform IC-RT-LAMP, on the basis of CP gene of the PVY genome, four specific primers including outer primers (F3 and B3) and inner primers (FIP and BIP) were used (Table 1) [4]. Even though the principles of the first section of IC-RT-LAMP assay exactly followed the IC-RT-PCR with no RNA extraction step, in the second part, a different methodology was employed, leading to a significant reduction in the time as well as the cost. The details are as follows:

Section 1: Just the same as the section 1 of IC-RT-PCR procedure (see above).

Section 2: Each reaction was performed in a total volume of $50 \mu \mathrm{l}$ : 10 mM DTT, 5 U of RNase Ribonuclease Inhibitor (Fermentas Co., cat. no. EO0381), $20 \mathrm{mM}$ Tris- $\mathrm{HCl}$, pH 8.8, $10 \mathrm{mM} \mathrm{KCl}, 10 \mathrm{mM}\left(\mathrm{NH}_{4}\right)_{2} \mathrm{SO}_{4}$, $0.1 \%$ Triton X-100, $2 \mathrm{mM}$ Betaine (Sigma-Aldrich, Oakville, ON, Canada), $1 \mathrm{mM} \mathrm{MgSO}{ }_{4}, 10 \mathrm{mM}$ each dNTP, $0.2 \mu \mathrm{M}$ each of F3 and B3, $0.8 \mu \mathrm{M}$ each of primer FIP and BIP, $1.25 \mathrm{U}$ of AMV reverse transcriptase (Fermentas Co., cat. no.EP0641) and $8 \mathrm{U}$ of Bst DNA polymerase (New England Biolabs Inc.). Tubes were then incubated at $60^{\circ} \mathrm{C}$ for $90 \mathrm{~min}$ in water bath. It is noticeable that the first $45 \mathrm{~min}$ is allocated only to synthesize cDNA, while in the second round, LAMP amplicons are amplified. An agarose gel electrophoresis system (optional; 1.5\%) under UV illumination could be also employed to visualize positive reactions.

\section{Colorimetric IC-RT-LAMP assay}

The details of colorimetric assay are described below:

Magnesium pyrophosphate: Like other metal indicators, magnesium pyrophosphate must be added before reaction. At the end of the amplification process, positive reactions were accompanied by a visible darker phase in the tubes in consequence of the formation of magnesium pyrophosphate $[13,35]$, which can be easily visualized with the naked eye. It is noticeable that the turbidity of the positive samples is stable but just for a short time, which should be consequently judged soon after taking out of the samples either from the water bath or the thermal cycler.

SYBR $^{\circledast}$ Premix Ex TaqTM II: To conquer time-dependent instability of magnesium pyrophosphate-based detection method, an alternative visual system using SYBR $^{\circledR}$ Premix Ex TaqTM II was employed $[20,25,36]$. Hence, $2 \mu$ SYBR $^{\circledR}$ Premix Ex TaqTM II (Perfect Real Time, Takara Bio Co., Ltd., RR081A) was added into each completely finished IC-RT-LAMP reaction containing $25 \mu \mathrm{l}$ of products; all positive reactions were effectively identified. Under UV illumination $(302 \mathrm{~nm})$, a green color pattern is an identical characteristic of all positive reactions as the same was monitored in this study.

Hydroxynaphthol blue (HNB) dye: In this protocol, $1 \mu \mathrm{l}$ of the hydroxynaphthol blue dye $(3 \mathrm{mM}$, Lemongreen, Shanghai, China) is mixed prior to amplification; all positive reactions can be easily identified using the naked eye, interestingly with no probable cross contaminations which usually arise from opened tubes after amplification [20,31-33]. In this context, a sky blue color pattern implies the existence of the reference virus, whereas a violet color change is observed when the control(s) are taken into consideration.

GeneFinder $^{\mathrm{TM}}$ : An obvious Green fluorescence pattern was observed to confirm positive IC-RT-LAMP products through visual observation with the naked eye when $1 \mu \mathrm{l}$ of GeneFinder ${ }^{\mathrm{TM}}$, diluted to $1: 10$ with $6 \times$ loading buffer (TaKara, Dalian, China), was added to each reaction as described previously $[29,30]$. Remarkably, concerning negative reaction, the original orange color could be observed.

SYBR Green I: $1 \mu$ l of SYBR Green I (Invitrogen, Sydney, Australia) diluted to 1:10 with $6 \times$ loading buffer was separately added to each reaction as described previously [36]. Remarkably, concerning negative reaction, the original orange color could be observed.

Ethidium bromide: About $0.5 \mu \mathrm{g}$ ethidium bromide/ml (Sigma) was added to each tube $[18,25,35]$. Under a UV transilluminator, positive products will be consequently marked if a detectable yellow color pattern is observed. As a result, the intensity of the fluorescent emissions moves up in positive tubes, while the reverse is true regarding negative tubes with no amplified fragments.

\section{Sensitivity and specificity of the LAMP assay}

Both quality and quantity of DNA template may have a dramatic influence on the results of each PCR method. To determine limit of the LAMP assay was compared with that of PCR, a seven dilution series $\left(2 \times 10^{0}\right.$ to $\left.2 \times 10^{7} \mathrm{CFU} / \mathrm{ml}\right)$ of $\mathrm{cDNA}$ were prepared in water; $2 \mu \mathrm{l}$ of each dilution was used for LAMP and PCR reactions. To determine specificity of the primers, LAMP and PCR reactions were carried out to PLRV (Potato Leafroll Virus) and CMV (Cucurbibta Mosaic Virus) cDNAs. Furthermore, SYBR Green I dye was added to LAMP products and positive reactions were directly detected by visual inspection. Similarly, the detection limit of the LAMP and PCR was approved by electrophoresis on $1.5 \%$ agarose gel.

\section{Results}

On the whole, 5 out of 95 leaf samples suspicious of having infection with PVY (5.3\%) showed positive responses against DAS-ELISA assay. All five samples, subsequent to nomination as PVY 16, PVY 28, PVY 45, PVY 78 and PVY 81, were utilized lastly for further analyses. As regards RT-PCR, following provide RNA template and cDNA (see "Materials and Methods" section for details), the amplification occurred via both backward and forward primers to generate ultimate products. The method, overall, could successfully identify five aforementioned positive samples. As expected, a fragment with the size band of $480 \mathrm{bp}$ was detected when the RT-PCR products were run on $1.5 \%$ agarose gel and stained with ethidium bromide (Figure 1a). The same as RT-PCR, RT-LAMP protocol could successfully identify five positive samples, interestingly with no use of cDNA but with use of RNA in a water bath directly. RT-LAMP amplicons were finally electrophoresed on a $1.5 \%$ agrose gel (as an optional system), and a large number of fragments (a ladder-like pattern) were eventually visualized (Figure $1 \mathrm{~b}$ ). The same as RT-PCR and RT-LAMP, our new IC-RT-PCR and IC-RT-LAMP
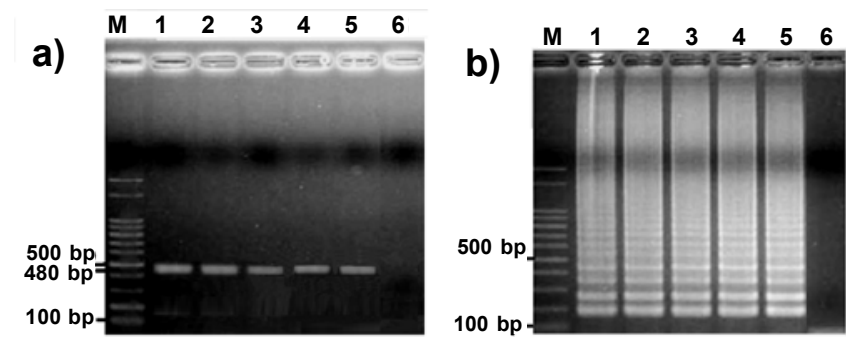

Figure 1: Gel electrophoresis pattern on 1.5\% agarose gel (a) RT-PCR assay (b) RT-LAMP assay. Left to right: lane M, DNA size marker (100 bp; Fermentas); lanes 1-5, PVY 16, PVY 28, PVY 45, PVY 78 and PVY 81, respectively; lane 6 , negative sample. 
Citation: Almasi MA, Dehabadi SH (2013) Colorimetric Immunocapture Reverse Transcription Loop-Mediated Isothermal Amplification Assay for Rapid Detection of the Potato virus Y. J Plant Pathol Microb 4: 188 doi:10.4172/2157-7471.1000188
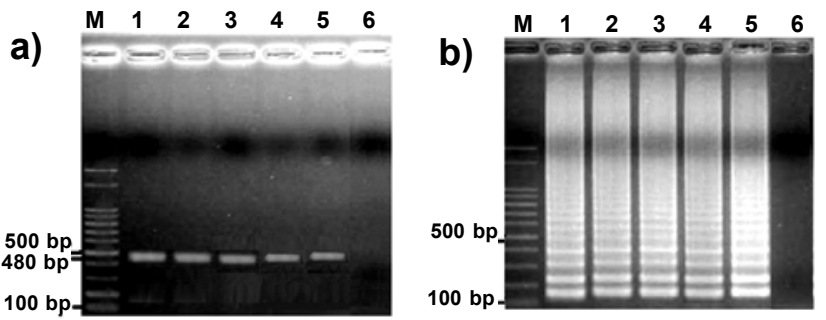

Figure 2: Gel electrophoresis pattern on $1.5 \%$ agarose gel (a) IC-RT-PCR assay; (b) IC-RT-LAMP assay. Left to right: lane M, DNA size marker (100 bp; Fermentas); lanes 1-5, PVY 16, PVY 28, PVY 45, PVY 78 and PVY 81 respectively; lane 6 , negative sample.
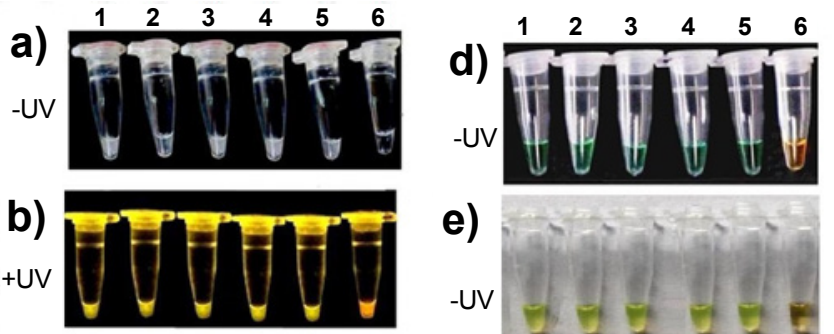

e)
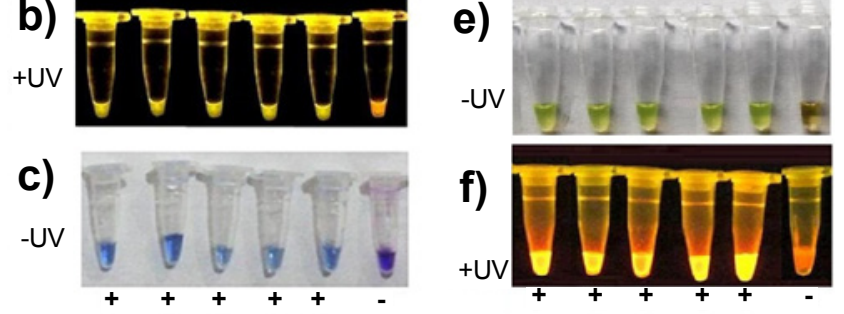

Figure 3: Detection of positive colorimetric IC-RT-LAMP reaction using six visualizing methods (different dyes) (a) magnesium pyrophosphate-based method; (b) SYBR ${ }^{\circledR}$ Premix Ex TaqTM II-based method; (c) hydroxynaphtho blue (HNB)-based method; (d) GeneFinder ${ }^{T M}$ based method; (e) SYBR Green I-based method; (f) ethidium bromide-based method. Left to right: tubes 1-5, PVY 16, PVY 28, PVY 45, PVY 78 and PVY 81, respectively; tube 6 negative sample.
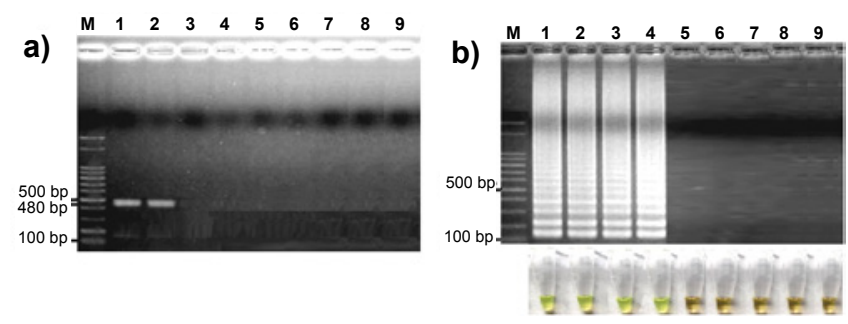

Figure 4: Comparative analysis of the sensitivity of LAMP and PCR, using a seven dilution series of cDNA as template (a) Electrophoresis analysis of PCR: (b) Electrophoresis analysis and visual detection (SYBR Green I) of LAMP. Left to right: Lane M, DNA size marker (100 bp; Fermentas); Lanes 1-8, 2×107, $2 \times 10^{6}, 2 \times 10^{5}, 2 \times 10^{4}, 2 \times 10^{3}, 2 \times 10^{2}, 2 \times 10^{1}$ and $2 \times 10^{\circ} \mathrm{CFU} / \mathrm{ml}$, respectively; Lane 9 negative sample.

protocols could successfully identify positive samples, interestingly with no use of RNA extraction and cDNA synthesis (Figures 2a and 2b). IC-RT-LAMP amplicons were able to be detected with the naked eye by adding different visual dyes followed by color changing in the solutions. In this regard, all used visual components could successfully make a clear distinction between positive infected samples and negative ones (Figures 3a-f). Our results, interestingly, indicated that LAMP can produce reliable products even under lower cDNA concentrations $\left(2 \times 10^{4} \mathrm{CFU} / \mathrm{ml}\right.$ or more), whilst PCR, requires higher level of cDNA (at least $2 \times 10^{6} \mathrm{CFU} / \mathrm{ml}$ ) (Figures $4 \mathrm{a}$ and $4 \mathrm{~b}$ ). Surprisingly, no false positive amplification was detected in specificity test and a $100 \%$ predictive value was obtained for PCR and LAMP assays (Figures $5 a$ and $5 b$ ).

\section{Discussion}

In this study, as a result, three detection methods including DASELISA, IC-RT-PCR and IC-RT-LAMP were assessed to explore positive and negative aspects of each one, followed by introducing the best one regarding PVY detection (Table 2). Even though all three techniques had enough potential to make differentiation and detect infected plant samples accurately, colorimetric IC-RT-LAMP proved to be much more useful as some factors including time, safety, simplicity, cost and being user friendly are taken into account:

Time DAS-ELISA as compared with IC-RT-LAMP and IC-RTPCR commonly needs a long time to identify positive infected samples (two or few additional days). In reality, with the exception of section one which takes equal time (see "Material and Methods" section), IC-RT-LAMP overall requires just $90 \mathrm{~min}$ to accomplish (as the least demanding detection method), while regarding IC-RT-PCR and DASELISA, $3 \mathrm{~h}$ and at least 1 day should be served, respectively. This, in turn, would simplify the detection procedure and result in saving of significant time needing for separating of the amplified products on the gel and the analyzing of the data which are commonly used in the other PCR-based methods.

Safety Regarding a number of detection methods, application of gel electrophoresis systems has emerged as a routine approach with enough potential to observe related amplicons. Just the same, such visual methods not only involve some expensive instruments but also during a period of time, exposure to the UV ray (because it is harmful to the eyes, even watching for a short period would irritate eyes and cause symptoms similar to conjunctivitis) as well as ethidium bromide could accompany a number of serious negative effects on researchers who use these methods $[17,25,30,33,36]$. More surprisingly, in IC-RTLAMP and other LAMP variants, amplified products can be easily visualized by means of different in-tube colour indicators with no essential requirement of additional staining systems; thus, toxic staining materials would be significantly avoided.

Simplicity, Cost and User Friendly Equipped labs with some molecular instruments as well as trained personnel are prerequisites
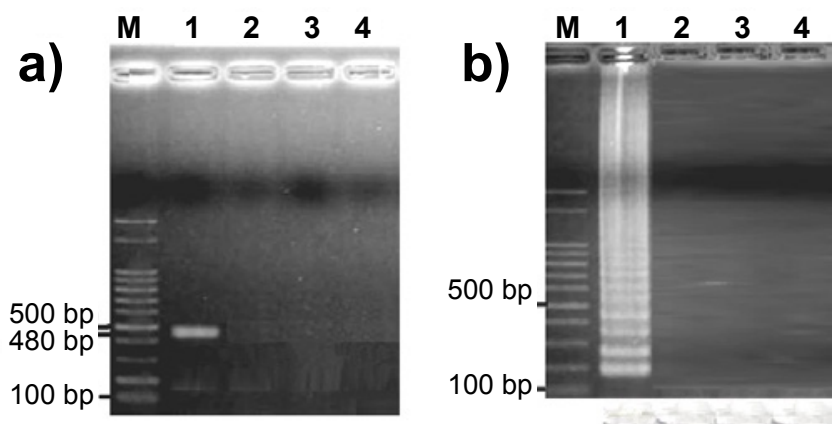

Figure 5: Comparative analysis of the specificity of LAMP and PCR (a) Electrophoresis analysis of PCR; (b) Electrophoresis analysis and visua detection (SYBR Green I) of LAMP. Left to right: lane M, DNA size marker (100 bp; Fermentas); lanes 1 PVY; lane 2 PLRV; lane 3 CMV; lane 4 negative sample. 
Citation: Almasi MA, Dehabadi SH (2013) Colorimetric Immunocapture Reverse Transcription Loop-Mediated Isothermal Amplification Assay for Rapid Detection of the Potato virus Y. J Plant Pathol Microb 4: 188 doi:10.4172/2157-7471.1000188

Page 5 of 6

\begin{tabular}{|c|c|c|c|c|c|c|c|c|c|c|}
\hline Assay & Total time & Detection method & Safety & $\begin{array}{l}\text { Need to } \\
\text { UV ray }\end{array}$ & $\begin{array}{l}\text { Need to } \\
\text { detect } \\
\text { instruments }\end{array}$ & Cost & $\begin{array}{l}\text { User } \\
\text { Friendly }\end{array}$ & Accuracy & $\begin{array}{l}\text { Need to RNA } \\
\text { extraction }\end{array}$ & $\begin{array}{l}\text { Need to cDNA } \\
\text { synthesis } \\
\text { separately }\end{array}$ \\
\hline DAS-ELISA & 1-2 days & $\begin{array}{l}\text { Visual + ELISA } \\
\text { reader }\end{array}$ & Yes & No & Yes & High & Low & High & No & No \\
\hline RT-PCR & 5 hours & Gel & & & & & & & & \\
\hline Electrophoresis & No & Yes & Yes & High & Low & High & Yes & Yes & & \\
\hline RT-LAMP & 120 minute & Visual+ Gel & & & & & & & & \\
\hline Electrophoresis & Yes & No and Yes & No and Yes & Low & High & High & Yes & No & & \\
\hline IC-RT-PCR & 3 hours & Gel & & & & & & & & \\
\hline electrophoresis & No & Yes & Yes & High & High & High & No & Yes & & \\
\hline IC-RT-LAMP & 90 minute & Visual+ Gel & & & & & & & & \\
\hline electrophoresis & Yes & No and Yes & No and Yes & Low & High & High & No & No & & \\
\hline Colorimeric IC-RT-LAMP & 90 minute & Visual & Yes & No & No & Low & Very high & High & No & No \\
\hline
\end{tabular}

Table 2: Comparison of DAS-ELISA, RT-PCR, RT-LAMP, IC-RT-PCR and IC-RT-LAMP assays.

to perform DAS-ELISA and IC-RT-PCR assays, all of which are undoubtedly costly. On the contrary, colorimetric IC-RT-LAMP can be easily accomplished just in a water bath or temperature block with no need of thermocyler and gel electrophoresis as the same results were recorded by Almasi et al. [17], Almasi et al. [18], Almasi et al. [25], Ahmadi et al. [33]. Likewise, exclusive of the primer designing process which is somehow complicated and sensitive, other phases are simply applicable. It is noticeable that in all RT-based methods, RNA extraction is an unavoidable step, needing different protocol(s) followed by optimization (mostly is a time-consuming process) to acquire purified RNA stock [12,37], whereas IC-RT-PCR and IC-RT-LAMP can be easily performed with no attempt for RNA isolation. The ICRT-LAMP method would lastly simplify the detection procedure and would result in saving of significant time which is needed for separation of the amplified products on the gel. On the other hand, the presence of LAMP and RT-LAMP-positive amplicons proved to be confirmed by adding a number of fluorescent or metal dyes to the reaction tubes, allowing observation with the naked eye $[18,30,33]$. In the current study, therefore, IC-RT-LAMP- amplified products were confirmed by adding all aforementioned visual systems (see "Materials and Methods" section), either prior to or after the reaction along with forming diverse color patterns depending upon the chemical characteristics of the applied chemical substances as dye.

\section{Conclusion}

In summary, a novel colorimetric IC-RT-LAMP assay for rapid and easy detection of PVY was developed here, its potential compared with DAS-ELISA RT-PCR, RT-LAMP and IC-RT-PCR assays. The method, on the whole, had the following advantages over the two mentioned procedures and also the methods including RT-LAMP and RT-PCR: (1) fascinatingly, no need of RNA extraction (2), no requirement of expensive and sophisticated tools for amplification and detection; (3) no post-amplification treatment of the amplicons; and (4) a flexible and easy detection approach, that is visually detected by naked eyes using diverse visual dyes. On the other hand, among different visual systems HNB, SYBR Green I and GeneFinder ${ }^{\mathrm{TM}}$ were proved to be more powerful. As the last point of view, the current diagnostic approach can be suitable not only for laboratory research but also regarding field diagnoses of many infectious diseases worldwide.

\section{References}

1. Potato Genome Sequencing Consortium, Xu X, Pan S, Cheng S, Zhang B, et al. (2011) Genome sequence and analysis of the tuber crop potato. Nature 475: 189-195.

2. Agindotan BO, Shiel PJ, Berger PH (2007) Simultaneous detection of potato viruses, PLRV, PVA, PVX and PVY from dormant potato tubers by TaqMan real-time RT-PCR. J Virol Methods 142: 1-9.

3. DeArce M (2008) Correspondence of Charles Darwin on James Torbitt's project to breed blight-resistance potatoes. Arch Nat Hist 35: 208-222.

4. Nie X (2005) Reverse Transcription Loop-Mediated Isothermal Amplification of DNA for Detection of Potato virus Y. Plant Dis 89: 605-610.

5. Clark MF, Adams AN (1977) Characteristics of the microplate method of enzyme-linked immunosorbent assay for the detection of plant viruses. J Gen Virol 34: 475-483.

6. Huttinga $H$ (1996) Sensitivity of indexing procedures for viruses and viroids Adv Botani Res 23: 59-71.

7. Holmes FO (1929) Local lesions in tobacco mosaic. Bot Gaz 87: 39-55.

8. Henson JM, French R (1993) The polymerase chain reaction and plant disease diagnosis. Annu Rev Phytopathol 31: 81-109.

9. Goto M, Shimada K, Sato A, Takahashi E, Fukasawa T, et al. (2010) Rapid detection of Pseudomonas aeruginosa in mouse feces by colorimetric loopmediated isothermal amplification. J Microbiol Methods 81: 247-252.

10. Blackburn P, Wilson G, Moore S (1977) Ribonuclease inhibitor from human placenta. Purification and properties. J Biol Chem 252: 5904-5910.

11. Berger SL, Birkenmeier CS (1979) Inhibition of intractable nucleases with ribonucleoside--vanadyl complexes: isolation of messenger ribonucleic acid from resting lymphocytes. Biochemistry 18: 5143-5149.

12. Steward GF, Culley AI (2010) Extraction and purification of nucleic acids from viruses, pp. 154-165. In Wilhem SW, Winbauer MG, Suttle CA [eds.], Manual of Aquatic Viral Ecology.

13. Notomi T, Okayama $H$, Masubuchi $H$, Yonekawa $T$, Watanabe $K$, et al. (2000) Loop-mediated isothermal amplification of DNA. Nucleic Acids Res 28: E63.

14. Hadersdorfer J, Neumuller M, Treutter D, Fischer T (2011) Fast and reliable detection of Plum pox virus in woody host plants using the Blue LAMP protocol. Annal Appl Bio 159: 456-466.

15. Mori Y, Notomi T (2009) Loop-mediated isothermal amplification (LAMP): rapid, accurate, and cost-effective diagnostic method for infectious diseases. J Infect Chemother 15: 62-69.

16. Fu S, Qu G, Guo S, Ma L, Zhang N, et al. (2011) Applications of loop-mediated isothermal DNA amplification. Appl Biochem Biotechnol 163: 845-850.

17. Almasi MA, Moradi A, Nasiri J, Karami S, Nasiri M (2012) Assessment of performance ability of three diagnostic methods for detection of Potato Leafroll virus (PLRV) using different visualizing systems. Appl Biochem Biotechnol 168: 770-784.

18. Almasi MA, Jafary H, Moradi A, Zand N, Ojaghkandi MA, et al. (2013) Detection of Coat Protein Gene of the Potato Leafroll Virus by Reverse Transcription Loop-Mediated Isothermal Amplification. J Plant Pathol Microbiol.

19. Fukuta S, lida T, Mizukami Y, Ishida A, Ueda J, et al. (2003) Detection of Japanese yam mosaic virus by RT-LAMP. Arch Virol 148: 1713-1720.

20. Almasi MA, Ojaghkandi MA, Hemmatabadi A, Hamidi F, Aghaei S (2013) 
Citation: Almasi MA, Dehabadi SH (2013) Colorimetric Immunocapture Reverse Transcription Loop-Mediated Isothermal Amplification Assay for Rapid Detection of the Potato virus Y. J Plant Pathol Microb 4: 188 doi:10.4172/2157-7471.1000188

Development of Colorimetric Loop-Mediated Isothermal Amplification Assay for Rapid Detection of the Tomato Yellow Leaf Curl Virus. J Plant Pathol Microbiol.

21. Saitou Y, Kobayashi Y, Hirano S, Mochizuki N, Itou T, et al. (2010) A method for simultaneous detection and identification of Brazilian dog- and vampire bat-related rabies virus by reverse transcription loop-mediated isothermal amplification assay. J Virol Methods 168: 13-17.

22. Haridas DV, Pillai D, Manojkumar B, Nair CM, Sherief PM (2010) Optimisation of reverse transcriptase loop-mediated isothermal amplification assay for rapid detection of Macrobrachium rosenbergii noda virus and extra small virus in Macrobrachium rosenbergii. J Virol Methods 167: 61-67.

23. Lee MS, Yang MJ, Hseu YC, Lai GH, Chang WT, et al. (2011) One-step reverse transcription loop-mediated isothermal amplification assay for rapid detection of Cymbidium mosaic virus. J Virol Methods 173: 43-48.

24. Soliman H, El-Matbouli M (2009) Immunocapture and direct binding loop mediated isothermal amplification simplify molecular diagnosis of Cyprinid herpesvirus-3. J Virol Methods 162: 91-95.

25. Moradi A, Nasiri J, Abdollahi H, Almasi M (2012) Development and evaluation of a loop mediated isothermal amplification assay for detection of Erwinia amylovora based on chromosomal DNA. Euro J Plant Pathol 133: 609-620.

26. Parida M, Shukla J, Sharma S, Ranghia Santhosh S, Ravi V, et al. (2011) Development and evaluation of reverse transcription loop-mediated isothermal amplification assay for rapid and real-time detection of the swine-origin influenza A H1N1 virus. J Mol Diagn 13: 100-107.

27. Hill J, Beriwal S, Chandra I, Paul VK, Kapil A, et al. (2008) Loop-mediated isothermal amplification assay for rapid detection of common strains of Escherichia coli. J Clin Microbiol 46: 2800-2804.

28. Tomita N, Mori Y, Kanda H, Notomi T (2008) Loop-mediated isotherma amplification (LAMP) of gene sequences and simple visual detection of products. Nat Protoc 3: 877-882.
29. Ren WC, Wang CM, Cai YY (2009) Loop-mediated isothermal amplification for rapid detection of acute viral necrobiotic virus in scallop Chlamys farreri. Acta Virol 53: 161-167.

30. Almasi MA, Erfan Manesh M, Jafary H, Dehabadi SM (2013) Visual detection of Potato Leafroll virus by loop-mediated isothermal amplification of DNA with the GeneFinderâ, $\phi$ dye. J Virol Methods 192: 51-54.

31. Goto M, Honda E, Ogura A, Nomoto A, Hanaki K (2009) Colorimetric detection of loop-mediated isothermal amplification reaction by using hydroxy naphtho blue. Biotechniques 46: 167-172.

32. Ma XJ, Shu YL, Nie K, Qin M, Wang DY, et al. (2010) Visual detection of pandemic influenza A H1N1 Virus 2009 by reverse-transcription loop-mediated isothermal amplification with hydroxynaphthol blue dye. J Virol Methods 167 214-217.

33. Ahmadi S, Almasi MA, Fatehi F, Struik PC, Moradi A (2012) Visual Detection of Potato leafroll virus by One-step Reverse Transcription Loop-Mediated Isothermal Amplification of DNA with Hydroxynaphthol Blue Dye. J phytopatho 161: 120-124.

34. Rowhani A, Stace-Smith R (1979) Purification and characterization of potato leafroll virus. Virology 98: 45-54.

35. Tsai SM, Chan KW, Hsu WL, Chang TJ, Wong ML, et al. (2009) Development of a loop-mediated isothermal amplification for rapid detection of orf virus. J Virol Methods 157: 200-204.

36. Cheng SJ, Chen ZY, Chu YN, Cui LB, Shi ZY, et al. (2011) Sensitive detection of influenza $A(\mathrm{H} 1 \mathrm{~N} 1)$ virus by isothermal amplification in a single tube. Chin $J$ Analyti Chem 39: 335-340.

37. Crowder CD, Rounds MA, Phillipson CA, Picuri JM, Matthews HE, et al. (2010) Extraction of total nucleic acids from ticks for the detection of bacterial and viral pathogens. J Med Entomol 47: 89-94. 